\title{
Learning, teaching and assessment of second foreign languages in Swedish lower secondary school - dilemmas and prospects ${ }^{1}$
}

\author{
Camilla Bardel, Stockholm University \\ Gudrun Erickson, University of Gothenburg \\ Rakel Österberg, Stockholm University
}

\begin{abstract}
This paper presents an overview of second foreign language (SFL) education in Sweden, especially at lower secondary level. It offers a survey of the historical development of the study of other languages than English as well as a reflection over the current state of the subject. Currently, there is a shortage of research on the circumstances and conditions of the learning, teaching and assessment of the Swedish school subject Modern languages, as well as on young people's proficiency in other languages than English in Sweden. In order to contribute to a knowledge base for further research, the current paper reviews work considering the Swedish context concerning: a) frame factors, policy issues and organization of SFL studies b) attitudes towards plurilingualism and SFL motivation, c) teacher education and recruitment policies, and d) levels of attainment at the end of compulsory school. Throughout the paper, the European context is also taken into account. The paper ends with a discussion of the general status of the subject Modern languages in Swedish school and society, the fact that this subject is not mandatory, and the consistently high dropout rate that characterizes the current situation.
\end{abstract}

Keywords: modern languages, second foreign languages, lower secondary school, attitudes, Sweden

\section{Introduction}

The situation as regards the study of foreign languages (FLs) other than English is often referred to as critical in Sweden. There is an ongoing discussion among school teachers and academics, and occasionally also policymakers and politicians, about the status of the study of those FLs that are learnt after English, henceforward referred to as second foreign languages (SFLs). Regularly, the debate flares up in the media, for example in daily newspapers, as well as in more specialized journals (see e.g., Bardel \& Novén, 2012; Elfving, 2002; Fahlén, 2018; Holmer, Gerdin, \& Söderberg, 2001). The background to this debate about the once-upon-a-time highly reputed school subjects German and French, more recently challenged by the introduction of Spanish as an option, and about the

Corresponding author's email: camilla.bardel@isd.su.se

ISSN: 1457-9863

Publisher: Centre for Applied Language Studies

University of Jyväskylä

(C) 2019: The authors

http:/ /apples.jyu.fi 
generally low interest in Swedish society for other languages than Swedish and English, will be focused upon in this paper. Existing studies and reports only give limited information about the situation and based on the fact that there is no current state of the art description available of SFL education in Sweden, and also because previous studies are few, the aim of the text is to contribute to a basis for further research into SFL education in Sweden and Europe. The method used comprises scrutiny of policy documents, reports and previous studies mainly of the Swedish context, which may constitute an interesting example of the current state and development of multi- and plurilingualism in Europe. A thorough search of studies has been made focusing on the state of the art in Sweden. Articles and studies from the 1990s and onwards have been included with the intention of giving a background. The field lacks systematic research and a thorough background description. Thus, this survey provides circumstances and backgrounds and the most recent research on the subject. The main focus will be on the first years of study of the SFLs or, using Swedish curriculum terminology, 'Modern languages', a subject currently introduced at the age of 12, that is, in school year six.

The main SFLs studied in Swedish lower secondary school are French, German, or Spanish, which since 1994 are contained in a group together with other languages, from which the students choose one. The phenomenon is referred to as Språkvalet or the 'Language choice', and it will be further presented in section 2.

The paper starts with a section focusing on policy documents and educational reports as well as previous academic work on frame factors, policy issues and the organization of SFL studies (2.1), attitudes towards plurilingualism and SFL motivation in Sweden (2.2.), teacher education, recruitment policies and changes in the curriculum (2.3.), and finally, the levels in Modern languages achieved at the end of compulsory school (2.4). In section 3, the dilemmas of the current situation for SFLs are brought up and discussed, and recent statistics from the Nordic countries are compared. In section 4, some conclusions are drawn and possible prospects are outlined.

\section{Previous developments and current state of the art}

\subsection{Frame factors, policy issues and organization of SFL studies in a historical perspective}

Looking back historically at foreign language education in Sweden, FLs were initially, and for many years, taught only to a small number of students in a very limited number of schools, after entrance testing, and as preparation for further education. In 1859, German became the first FL to be studied (French had had this role in the early 19th century) and kept this role until 1946, when it was replaced by English as the first FL to be taught in Swedish schools. Between 1950 and 1962, in a series of trials, English was made compulsory for all students from school year 5 in obligatory lower secondary education, and French and German became additional options ${ }^{2}$. Until 1969, the study of an additional FL, on top of English, was a requirement for those who aimed for continued studies at upper secondary level. For early studies focusing on the development of foreign language education in Sweden, see e.g., Henriksson (1960), Bratt (1977, 1984), and Hammar (1981). 
Since the time when English became a compulsory subject, the status of this language has improved continuously. SFLs have a very different status, being optional in lower secondary school but compulsory in academically oriented study programs in upper secondary school (for thorough descriptions and analyses of the history and status of SFLs in Sweden, see Marklund, 1985; Tholin, 2017). For long, the two foreign languages offered in addition to English in lower secondary school were German and French, with German as the dominating option. However, other languages were also studied, especially in upper secondary school, Spanish being one of them, gradually attracting more students (Riis \& Francia, 2013). In the curriculum for compulsory education introduced in 1994 ('Lpo94'), Spanish was made one of the explicit Modern language options in lower secondary school, beside German and French. Within the Language choice, one of these three languages became an option. Swedish independent schools, as well as municipalities, are held by the Swedish Education Act to offer at least two of the three languages French, German and Spanish. Other options within the Language choice are additional studies in Swedish and/or English, Swedish as a second language, and Sign Language for hearing. In addition, students with an immigrant background are allowed to choose their native languages (Utbildningsdepartementet, 1994).

Spanish soon became the most popular of the three SFLs and is currently (2018) studied by the majority of students having chosen the Modern language option in comprehensive school. According to annual statistics published by the National Agency for Education (NAE) ${ }^{3}$, the proportion 2017 between the final grades awarded at the end of school year 9 ('Moderna språk, språkval'/ $n=71,606$ ) was $54.7 \%$ for Spanish, $24.8 \%$ for German and 19.9\% for French (the remaining $0.6 \%$ being mainly Chinese, Finnish and Arabic).

In connection with the introduction of new national curricula in 1994, significant structural changes were made to second foreign languages in lower secondary school. These were further elaborated in the revision of the language syllabuses in 2000 . The ambition was to increase the number of students taking an additional FL and also to make the aims of the syllabus more attainable than before (for further information, see Skolverket, 2000; Tholin, 2017). Hence, the number of hours of SFL instruction (Modern languages) was increased by c. $25 \%$, the learning objectives were slightly modified, and national assessment materials both of a formative and summative kind were gradually introduced, however presented as an optional, and consequently not mandatory for schools to use (cf. section 2.4). Furthermore, it should be noted that, in the late 1970s, the National Board of Education had had plans to make a SFL compulsory in lower secondary school (Skolöverstyrelsen, 1978). This idea, however, turned out not to be supported by many language teachers: a survey of attitudes carried out some years later among teachers of French and German showed that only $12 \%$ were in favor of the proposed reform (Skolöverstyrelsen, 1991). Strong doubts regarding the advantage of two foreign languages being mandatory were also articulated in the journal published by the Swedish Language Teachers' Association (Holmer et al., 2001). It should be noted, however, that these doubts were not the official standpoint of the association, in which opinions were - and still are - divided (see further section 4 ).

Although there is a shortage of research on the societal, school-related and individual factors that may be significant for young people's chances to learn a SFL in Sweden, several educational reports and studies from the past two decades have described the conditions of the subject Modern languages. A number of 
studies focusing on the situation for SFLs in Swedish language education have been undertaken since the curricular reforms in 1994, 2000 and 2011, alongside investigations with different aims made by the national educational authorities. In the following, a brief account of some of them will be given.

Sörensen (1999), commissioned by the NAE, conducted a pilot study of the boosted language programme for lower secondary school introduced in the 1994 curriculum. Following interviews with head teachers, teachers and students in three schools, he reported on emerging changes. As expected, the number of hours of instruction for SFLs had increased, according to the new regulations, and the start of SFL studies had in many cases been lowered from grade seven to six; about $80 \%$ of all students chose to study one of the languages offered. While students were generally satisfied with beginning a new language in grade six, teachers found the changes challenging, due both to organizational difficulties following the increased number of students, most of them younger than before, and to the fact that students in grade six often went to schools where SFL instruction had not been offered earlier, which brought about considerable difficulties at the organizational level. Furthermore, Sörensen (1999) found that more than a fifth of the students, mostly boys, dropped out from their SFL studies before the end of compulsory school.

Thorson, Molander-Beyer and Dentler (2003), in collaboration with teacher students, focused on SFLs in upper secondary school by analyzing questionnaires answered by students $(n=581)$ and teachers $(n=52)$ at six large upper secondary schools in a big Swedish city. The study, characterized by the researchers as quantitative with some qualitative elements, aimed to investigate the current status of Modern languages, the reason for students to drop out, in lower as well as upper secondary school, and to tap students' and teachers' attitudes to languages and language studies. The study gives fairly clear indications of some of the reasons for students abandoning SFLs, one of them being what was perceived by both students and teachers as the considerable amount of time and effort required for learning success. Furthermore, a number of students pointed out that the instruction provided was fairly monotonous and needed to change towards a more functional and authentic approach. This opinion was usually not articulated by the teachers in the study.

In a report on Modern languages in lower secondary school (Skolinspektionen, 2010), the Swedish Schools Inspectorate reported on conditions that, indirectly, resemble what students in the above-mentioned study expressed: they found that the target language was used only to a small extent, both by students and teachers. Furthermore, it was pointed out that the reasons for dropping out from the SFL studies were hardly ever analyzed by schools and that very little support was offered to those students who would need it in order not to give up their studies.

Tholin and Lindqvist (2009) set out to analyze the possibility offered to students in lower secondary school to study additional Swedish and English as an option within the compulsory Language choice instead of a SFL. In their study, in which a multi-methods approach was used for data collection, Tholin and Lindqvist also gained substantial insight into the situation for the SFLs. The conclusion reached was that for most students, the Swedish/English option was a waste of time and should either be abolished or thoroughly reformed, and that introducing compulsory studies of a SFL in lower secondary school would be a logical step to take. In a response to a government commission regarding language studies in lower secondary school (Skolverket, 2011a), the NAE suggested, in line with Tholin and Lindqvist (2009), to abolish additional Swedish 
and English as an alternative within the framework of the Language choice, but to keep English for beginners and Swedish as a second language ${ }^{4}$. As for SFLs, the possibility for schools to award grades for the first proficiency level in the syllabus at the end of lower secondary school was suggested. This would give students the possibility to pass with the first course level of the Swedish language syllabuses. Currently, the level required at the end of compulsory school is the second course. In European terminology, this meant that an A1 level should be introduced, alongside the current A2.1, at the end of school year nine. The suggested introduction of a lower exit level from compulsory school would thus enable continued studies at the second course in upper secondary school. In addition to this suggestion, massive in-service training for SFL teachers was proposed. No official response from the political level was given to the proposal made by the NAE in 2011; however, certain traces of what was suggested can be found in an extensive program for digital in-service training for teachers of SFL, launched in the autumn of 2018 (referred to as Språksprainget ${ }^{5}$ ), as well as in a renewed proposal from the NAE regarding SFLs (see section 4).

In the wake of the European Survey on Language Competences in 2011, where the Swedish results for English were found to be at the top among the participating countries and those for Spanish at the bottom (Skolverket, 2012a), much attention was given to the situation for Spanish in Swedish schools (Riis \& Francia, 2013; Skolverket, 2013). The European study and its results will be focused upon later in this article, as will the issue of attitudes to SFLs and motivation for SFL studies.

In 2016, The National Union of Teachers in Sweden published a report partly based on a questionnaire survey among c. 750 members teaching Modern languages (Lärarnas Riksförbund, 2016). The results indicated a critical situation for Modern languages with regard to shortage of teacher students, and consequently also of future teachers, as well as teachers' perceptions of employment conditions and the profession as such (see also section 2.3). For example, during the last three years, more than $60 \%$ of the respondents had considered leaving the profession. Articulated areas of concern were unsatisfactory salaries, heavy work load, teaching in heterogeneous groups, and lack of in-service training. More than half of the respondents had not received subject related in-service training during the last five years. However, a recent research project on Modern languages (the TAL project) ${ }^{6}$, comprising a questionnaire answered by 315 teachers at randomly sampled schools in Sweden, gives a somewhat different picture, $80 \%$ of the respondents declaring that they would choose to become teachers of Modern languages again, if they were to make a new decision (Erickson, Österberg, \& Bardel, 2018).

In a recent article, Tholin (2017) discusses the current situation for SFLs in lower secondary school in relation to the efforts made at the national level to increase the number of students choosing and also completing their language studies. As reported above, steps had been taken in the 1990s to achieve this by increasing teaching time by $25 \%$ and making the learning goals more attainable. The study shows that these changes have had very little effect, if any: The situation regarding the number of students and their achievement of syllable goals has not changed much from the time before the reforms. Tholin (2017) points at three interactive factors that may explain this: the non-existence of a central school administration in Sweden that concretizes political intentions; teachers not perceiving the reforms as important, and a gap between policy intentions and research-informed knowledge about the motives underlying students' decisions. 


\subsection{Current attitudes towards plurilingualism and SFL motivation}

The Eurobarometer 386 (European Commission, 2012a) indicates that Swedes have a generally positive attitude towards learning foreign languages, especially English, but, to some extent, also German. It clearly shows the special status of English among Swedes, when it comes to their self-esteem of communicative skills and attitudes towards learning and using the language. Swedes generally have a higher self-esteem regarding their own competences in foreign languages than the rest of the Europeans on average, especially so when it comes to English: 54\% of the EU-citizens that answered the questionnaire deemed themselves capable of having a conversation in at least one FL; $25 \%$ of them in at least two FLs. The corresponding figures for the Swedish respondents were $91 \%$ and $44 \%$, respectively. The high number of Swedish respondents who consider themselves able to have a conversation in at least one FL seems to mirror the fact that English, which is the first FL studied in Sweden, is also a language that is unofficially taking on the role of a second language in Swedish society, due to a high degree of extramural use of English (Falk, Lindqvist, \& Bardel, 2015; Hyltenstam, 2004).

Swedish adults point out especially English, but also German, as fundamental for their personal development. Swedish young people as well consider English the most important language to know, but they also ascribe Spanish a certain importance (European Commission, 2012a). However, young Swedes do not consider German or French as valuable as do their European peers. As mentioned before, Spanish is the most popular language option in the Language choice, which is made before the start of the sixth school year.

A twofold conclusion that can be drawn from the Eurobarometer is that Swedes, more than other Europeans, consider it important to know one language alongside the mother tongue, but that they are more sceptical than others to the idea of having to learn more than one FL. This reflects the perception of many Swedes, pointed out by e.g., Henry (2012) and Cabau-Lampa (2007), that knowing English is enough to get by in society.

Eurobarometer 386 also shows that the hypothetical idea of being offered free studies in a new language does not attract Swedes; it does not increase their motivation to learn a new language and this distinguishes them from other Europeans, who would find the possibility rather motivating, according to the survey. The response does not necessarily have to be interpreted as reluctance to learn additional languages. It is possible that what lies behind this answer is instead a certain scepticism among Swedes towards formal language learning and a preference to acquire languages informally, outside the classroom. Swedes are used to acquiring English in this way, at least in part, English being highly present in the Swedish linguistic landscape, on television, in musical lyrics etc. It is a wellknown fact that English input has a longstanding presence in Sweden as compared to many other European countries. Young people and adults alike are, and have been for decades, exposed to English input through different media, and young people's formal learning of English is more than ever before enhanced through out-of-school activities, especially on the Internet (see e.g., Sylvén \& Sundqvist, 2012).

Young Swedish students' motivation for learning a SFL has been thoroughly investigated by Henry (e.g., 2012). Following Dörnyei's framework of the L2 self (see e.g., Dörnyei \& Ushioda, 2009), and adapting it to L3 learning, Henry and Apelgren (2008) compared young learners in school years 4, 5 and 6 . The learners who had not yet started to study a SFL were generally positive to the idea of doing 
so and they easily imagined themselves as future speakers of the language. However, the students in year 6 (the first year) felt that the classroom activities did not correspond to their expectations, and they did not display as positive attitudes towards the SFL as did the younger learners who had not yet begun SFL studies. In Henry (2009), 169 students from this latter group were followed up, and it turned out that their attitudes toward foreign languages generally, as well as their motivation to learn the SFL in question, were notacibly lower than it had been in year 6. For other results on SFL motivation in Sweden, especially Spanish, see Österberg (2008) and Cardelús (2015).

\subsection{Teacher education, recruitment policies and changes in the curriculum}

The role of the teacher has changed considerably in Sweden during the last 30 years. Several reforms of the school system and of teacher education have taken place, the most recent being from 2011. In this latest reform, emphasis was put on subject specific educational studies, language education being one example. Critical voices have claimed that the reform lead to a scattered and shallow program for teachers at secondary school (Arevik, 2012; Larsson, 2013). Three subjects, and only 45 ECT in French, German or Spanish, are required to become a certified teacher of Modern languages in secondary school. Furthermore, the students have limited options when it comes to combination of subjects. An informative overview of the current situation is given in Lalander (2014, pp. 2-5).

Logically, the role of the SFL teacher education is closely linked to curricular and organizational changes. One of the most recent changes is the introduction of the requirement of teacher certification, which was implemented in the Education act in 2011. This has had repercussions especially on the profession of Spanish teachers, where three teachers out of four had no graduation from teacher education, according to Riis and Francia (2013) by the time of their study. Furthermore, the authors point out that there is a lack of SFL teachers generally, and that the numbers of newly examined SFL teachers are low. The difficulties for school leaders to recruit new teachers of French, German and Spanish have also been pointed out in an analysis of the number of teachers examined at Swedish universities in the new teacher education from 2011 (Riksrevisionsverket, 2014). From their survey they found that there is a lack especially of teachers of mathematics, sciences and Modern languages for year 7-9, and that it is difficult to recruit new ones. This is an important finding, considering the urgent need of new language teachers in a near future. Lärarnas Riksförbund (2016), as referred to in section 2.1., anticipated that, in order to cover vacancies related to up-coming retirements, it will be necessary to hire as many as 5700 new SFL teachers during the period from 2016 until 2029. The lack of SFL teachers is especially problematic for Spanish, where the need has grown gradually and considerably since Spanish became an official option in 1994. Figures of the admissions of subject teacher students for school years 7-9 and upper secondary level in 2014 are reported in table 1. 
Table 1. Choice of subject in the teacher education programs for years 7-9 and upper secondary level 2014 (Riksrevisionsverket, 2014, p. 36).

\begin{tabular}{ll|ll}
\hline & \multicolumn{2}{|c}{ Upper secondary } \\
\hline Top ten (n) & $\begin{array}{l}\text { Ten lowest number } \\
\text { of applicants (n) }\end{array}$ & Top ten (n) & $\begin{array}{l}\text { Ten lowest number } \\
\text { of applicants (n) }\end{array}$ \\
English (222) & French (3) & History (913) & Italian (3) \\
History (217) & German (3) & English (907) & Latin (4) \\
Sport (139) & Spanish (5) & Swedish (613) & Psychology (16) \\
Swedish (126) & Chemistry (8) & Social science (560) & Technology (22) \\
Religion (117) & Mother tongue (10) & Music (384) & Dance (24) \\
Mathematics (96) & Physics (11) & Religion (375) & French (27) \\
Social science (69) & Technology (17) & Mathematics (325) & German (28) \\
Geography (60) & Music (18) & Sport (315) & Science (28) \\
Slojd (50) & Biology (20) & Art (130) & Chemistry (34) \\
Swedish as a L2 (41) & Home economics (26) & Swedish as a L2 (104) & Physics (40) \\
\hline
\end{tabular}

As seen, French, German, and Spanish are found at the lowest end regarding the number of applicants for teacher education programs preparing for teaching at lower secondary level. In the upper secondary level teacher program, French and German, together with Italian, are found among the ten less attractive subjects. A somewhat brighter situation is found for Spanish, which does not appear in any of the categories, but somewhere in between (not accounted for in the report), and furthermore, Spanish is reported to be among the ten most applied for of the subjects studied on individual basis outside the program by future teachers as from the year 2011 (Riksrevisionsverket, 2014, pp. 62-63).

Because of the low number of applicants, for many years, there has been no, or very little, competition in the admission to teacher education programs. Generally, the perceived status of teachers has declined and the education has been criticized for not being academically up to date. During a long period, the whole program was characterized by a decline in admission requirements and numbers of applications, starters with generally low grades and low proficiency levels of the subject itself. Furthermore, many students abandon the program (Bertilsson, Börjesson, \& Broady, 2009; Högskoleverket, 2009). For example, almost $50 \%$ of the teacher students in Stockholm dropped out during the academic year 2001-2002 (Hemmingson, 2007; Lalander, 2014). A new program was introduced in 2011 and the number of applicants to teacher programs generally has since then been slightly growing (even if not for the subject teacher program for years 7-9, as shown in table 1), but there is still a high share of students that drop out from the program (Lalander, 2014; Zaccheus, 2013).

\subsection{Levels of attainment at the end of compulsory school - intended, implemented and attained curriculum ${ }^{8}$}

\subsubsection{Intended and implemented curriculum}

The definition of language competence in the Swedish national syllabuses - that is, what is to be taught and learnt - is clearly communicative and functional. This has been the case since the publication of the national curriculum for lower secondary school in 1980, Lgr 80, the development of which was strongly 
influenced by the work of the Council of Europe, in which Sweden had an active role (Andered, 2001; Erickson \& Pakula, 2017; Söderberg, 2011; Takala, 2013). The functional approach was further emphasized in the 1990s, due to the influence from the early drafts of the Common European Framework of Languages (CEFR, Council of Europe, 2001), in which an action-oriented view of language use is in focus.

The 1994 curriculum in particular contained clear metacognitive goals, that is, goals focusing on students' ability to plan, accomplish and assess their work. The first national tests of English from 1998 in the new goal oriented system used terminology from the preliminary version of the CEFR; instead of the traditional abilities listening, speaking, reading and writing, oral production and interaction, receptive skills and written production - later with the addition of written interaction - were used (Erickson \& Pakula, 2017, pp. 15-16). The influence from the CEFR became very clear when the national language syllabuses were revised in 2000, for example regarding the action oriented approach and the introduction of interaction and intercultural competence (Erickson \& Pakula, 2017, p. 16). Since the curriculum reform in 2000, there are two parallel national syllabuses for foreign languages in Sweden, one for English and one for Modern languages, the latter referring to all second foreign languages (except Chinese, which has its own). The two syllabuses are identical regarding content and performance standards, although progression is faster for English as well as level demands. The original intention was to use the six levels of the CEFR, but eventually, after long discussions, it was not deemed possible. This was due to the very different current circumstances prevailing for English on the one hand and other foreign languages on the other, both in the Swedish society and in the curricula, regarding the opportunities for extramural learning as well as the amount of teaching time stipulated in the national curriculum (Erickson \& Pakula, 2017). As pointed out by Erickson and Pakula (2017, p. 16) the CEFR was translated into Swedish in 2009, during the phase of preparation for the most recent curriculum reform. For an anthology on the use of the CEFR in the Swedish school context, see Söderberg (2011).

The current Swedish syllabuses for English and Modern languages are explicitly linked to the levels of the CEFR, albeit in a tentative way, due to the lack of empirical studies of test results. This alignment has been made by several rounds of textual analyses and holistic peer analyses of national tests (Erickson \& Pakula, 2017). In the latter, international experts on the CEFR analysed the national materials and their underlying syllabuses for English and Modern languages in relation to the CEFR from content as well as performance perspectives (Erickson, 2017). In general, these estimates coincide well with the official comparison made in the syllabuses, however with one exception: In the Swedish syllabuses, minimal levels of proficiency are explicitly defined for each level, which sometimes causes comments on a certain degree of leniency in the peer analyses and discussions of the national tests, especially regarding the Pass grade. On the whole, though, the studies confirmed the estimation that to receive a Pass at the end of compulsory school, students need to be at CEFR level B1.1 for English, and for Modern languages at level A2.1.

\subsubsection{Attained curriculum}

Generally, there are mainly two measures of attainment, or student achievement, in relation to the national syllabus goals at the end of compulsory school, namely grades awarded by teachers and results from national tests. Analyses of grades in 
English and the three modern languages generally chosen in lower secondary school, compiled from the NAE website (www.skolverket.se), show the following average grade values for the end of school year 9 between 2013 and 2017, with 20.0 as the maximum ${ }^{9}$ (for English for the whole cohort, $n=>100,000$; for Modern languages for groups of between 13,000 and 39,000, depending on language and cohort):

Table 2. Final grades school year 9, English, French, German, Spanish + average grade value (max. 20) for 19 school subjects.

\begin{tabular}{llllll}
\hline Language & $\mathbf{2 0 1 3}$ & $\mathbf{2 0 1 4}$ & $\mathbf{2 0 1 5}$ & $\mathbf{2 0 1 6}$ & $\mathbf{2 0 1 7}$ \\
\hline English & 14.3 & 14.4 & 14.5 & 14.3 & 14.1 \\
$\begin{array}{l}\text { French } \\
\text { German }\end{array}$ & 14.2 & 14.1 & 14.4 & 14.3 & 14.6 \\
$\begin{array}{l}\text { Spanish } \\
\begin{array}{l}\text { Average grade } \\
\text { values for 19 } \\
\text { school subjects }\end{array}\end{array}$ & 13.7 & 13.7 & 13.9 & 14.2 & 14.2 \\
\hline
\end{tabular}

As shown, the achievement at the end of compulsory school of Swedish students in languages is ranked relatively high, the average grade values for the four languages being consistently above the average grade values for all 19 subjects. This is a phenomenon worthy of discussion, however too far-reaching for the scope of this article. What should be born in mind though, is that the choice of an SFL is not compulsory; only c. $80 \%$ of all students in a cohort choose to study one of the modern languages offered, which obviously entails some selectivity. The number of students abandoning Modern languages before the end of year nine can also be assumed to affect the grades. Further, a certain degree of variability from one year to another can be noted for all languages. Although the values build on mandatory reporting from all schools in the country, the results should be interpreted with caution: a certain degree of data loss that can be assumed to influence the results.

Regarding the second source of information about levels of achievement in languages, national tests exist only for English. As mentioned in section 2.1, national assessment materials are however offered also for French, German and Spanish, although on a non-mandatory basis ${ }^{11}$. The materials, albeit developed according to the same quality principles as the English tests ${ }^{12}$, have a different structure, with subtests for different competences being offered - and scored separately, and with no aggregate test grade. (In the English national tests, there are three compulsory subtests, focusing on receptive, productive and interactive competences, reported separately but finally aggregated into a single test score).

Moreover, due to the non-mandatory status of the materials for Modern languages, the reporting of results is optional and cover only the components of the materials that teachers and/or schools have decided to use. Consequently, the results that are available are not complete and also highly self-selected, which means that they cannot be used for comparisons over time. However, both the test results that are actually reported and those generated in large pretesting rounds (c. 400 randomly selected students per task) indicate that the levels achieved are quite reasonable in relation to the intended target level, course 2 in the Swedish system, roughly equivalent to an A2.1 in the CEFR. This is further confirmed by 
the holistic peer analyses conducted by CEFR-experienced colleagues in other European countries mentioned earlier (Erickson, 2017; Erickson \& Pakula, 2017).

The results for the national tests of English, grade 9, i.e., by the end of compulsory school, are high as compared to other subjects in the national testing system and have been so since the introduction of the tests within the criterion referenced system introduced in the 1990s. In the current six-point grading system, the average, aggregate test grade is a $\mathrm{C}$, with a somewhat wider distribution for the results related to reception, i.e., listening and reading comprehension, than for oral and written production and interaction.

\section{International survey(s)}

As opposed to studies of first language, mathematics and science (e.g., the PIRLS, PISA and TIMSS surveys), very few large-scale, international studies have focused on foreign languages. In the 1970s, English and French at the end of compulsory school were investigated (Carroll, 1975; Lewis \& Massad, 1975), and a limited survey of English in eight European countries, including Sweden, was conducted in 2002 (Skolverket, 2004). However, in 2011 a large-scale, EU-funded survey of the five most frequent school languages in Europe was undertaken. The survey European Survey on Language Competences (ESLC) - included 16 school systems in 14 different countries. The survey, conducted at the end of lower secondary school, in Sweden school year 9, comprised tests of reception and writing. As for reading and listening comprehension, only closed formats were used, mostly multiple choice, and writing was assessed through tasks with very strict instructions. Speaking was not included in the ESLC, neither as production nor as interaction. No aggregation into a single summary score was made, but results for the different tests were reported individually on the CEFR scale. Background data were collected through questionnaires to students, teachers and head teachers.

Each participating country took part with its two most frequent foreign languages, which meant English for all countries but the UK, and most often German or French as SFLs. Spanish was represented as SFL by two countries, namely France and Sweden, and Italian by only one, Malta (European Commission, 2012b; Skolverket, 2012a).

The Swedish results for English were very high. For both reading and listening comprehension, they were at the top, even higher than those for Malta, where English is an official second language. Results for Swedish students' writing skills were slightly lower, but Sweden still achieved the second highest results among the participating countries, Malta being at the top (European Commission, 2012b; Skolverket, 2012a). The Swedish results for Spanish however proved to be very low, both compared to other SFLs in Europe, and to the French results for Spanish. On average, c. $35 \%$ of the results from Sweden were considered at pre-A 1 level, and only around $14 \%$ at level A 2 or above.

The very weak results for Spanish have been discussed from a number of different angles, not least in relation to the general lack of teachers of Spanish in Sweden, and in particular the shortage of certified teachers of Spanish. However, other aspects have also been touched upon, for instance, exposure to Spanish outside school, teaching traditions, and student motivation (e.g., Riis \& Francia, 2013; Skolverket, 2012b, 2013). The fact that no corresponding results for French and German in Sweden are available is obviously a drawback and a complication when it comes to generalizing the results to other modern languages. 


\section{Dilemmas}

From what has been said in the foregoing, it is possible to trace several dilemmas related to the study of SFLs in Swedish lower secondary school. The situation for SFLs in Sweden seems to be characterized basically by a number of interdependent factors, which are all in some way indicators of a relatively low degree of interest for SFL at different levels of society. An important background factor at the societal level is that the Swedish school-system is decentralized, leaving full responsibility to municipalities for deciding how resources should be allocated and to schools for fulfilling the goals set in the curriculum and subject syllabuses (for discussion, see Tholin, 2017).

There is a general lack of SFL teachers in Sweden, and it is particularly difficult to recruit language teachers for lower secondary school. Generally, the number of employed language teachers without a teaching degree and a certification is considerable, especially so for Spanish.

The optional status of Modern languages in lower secondary school is, as we will argue, a fact that may well contribute to the generally low status of these languages, which is sometimes defined in relation to the high status of English among Swedes. As opposed to English, which is in practice and informally approaching the status of a second language in Sweden (Falk, Lindqvist, \& Bardel, 2015; Hyltenstam, 2004), although with no such official status, the SFLs suffer from problems related to student motivation and attitudes (cf. e.g., Henry, 2012). Along with Swedish, English is encountered at very early ages outside as well as inside school, and it is a compulsory subject for all students up to the final school years. When it comes to other European languages, there are few opportunities for exposure and use outside the classroom, and the educational challenges are many. Hence, the situation is far from the Presidency conclusions of the Barcelona European Council 2002, where teaching at least two foreign languages from early age is called for as a strategic action to improve the mastery of basic skills (European Council, 2002, p. 19). Furthermore, the very fact that a SFL is not mandatory, may well have an impact on students' attitudes when it comes to the perceived importance of learning and knowing an additional language, i.e., the subject as such. Also, the fact that you can actually decide to drop the subject may well affect students' attitudes - as it most probably would, had it been another subject instead.

\subsection{Mandatory SFL in lower secondary school?}

Though the large majority of students (c. $80 \%$ ) choose a SFL and start studying French, German or Spanish in the $6^{\text {th }}$ grade (up til autumn 2018 the $6^{\text {th }}$ or the $7^{\text {th }}$ grade), the study of Modern languages is not compulsory, only the Language choice as such, and approximately $20 \%$ of the students drop out from the subject before leaving lower secondary school. This proportion has been more or less constant during two decades (Sörensen, 1999; Tholin, 2017; Tholin \& Lindqvist, 2009).

Questions often asked are why this is so, what can be done to raise students' motivation to choose a SFL and what can be done to make them stay with it until the end of compulsory school in year 9. In light of the fact that the languages taken within the Language choice constitute the only subject that can be discarded by 
students - who may have different reasons to do so - without any severe consequences, we argue that these questions are not the most adequate.

Different measures have been taken to promote the study of SFLs in Swedish schools. As from 2014, students who complete their studies of a Modern language in year 9 are allowed to use this extra grade when applying for upper secondary school.13 Between the years 2006 and 2010, credit implements ('meritpoäng') for studies at certain levels of Modern languages, English and mathematics were introduced (Tholin, 2017, p. 7; Utbildningsdepartementet, 2017, p. 14). If a student continues in upper secondary with his/her studies of the SFL from lower secondary school, extra credits will fall out. However, these measures do not seem to have had any major effect on the drop-out rate in lower secondary school, considering data reported on the NAE website. ${ }^{14}$ Hence, it seems plausible that the reason for some students to abandon the subject is the mere fact that they can do so.

Comparing the Swedish situation for SFLs with a neighbouring country, Norway, things are rather similar. The correspondent subject, fremmedspråk, is studied by an even smaller share of students; c. 35\%, in lower secondary school study a SFL. Additional Swedish and/or English has its counterpart, and another alternative to SFLs is in-depth maths. Carrai $(2014$, p. 21) describes the situation in the following way (translated from Norwegian): 'The SFL is neither compulsory nor optional: The student has to choose it from many options'. However, if the student plans higher education, he or she must take a SFL at upper secondary level.

Carrai (2014, pp. 39-40) also describes the other Nordic countries, where the situation is different. In Denmark, French or German may be studied from 11 years (European Commission, 2017, pp. 12, 35, 153), German being the most common choice (Eurostat Newsrelease, 2017, p. 2). Students who aim at continuing with a study program preparing for higher education must study a SFL in years 7 to 9. In upper secondary, Spanish becomes an option. In Finland, two combinations of three languages are compulsory: either a) Swedish and Finnish (which are both official languages) plus English or one other foreign language, or b) one of the official languages (Swedish or Finnish), English and another foreign language. English is by far the most studied first compulsory language (https://www.oph.fi/english/current_issues/101/0/statistics_of_the_month_m ost_basic_education_pupils_in_finland_learn_two_languages). In Iceland, English and a Scandinavian language are compulsory. Danish is the most popular choice among the Scandinavian languages. It is possible, but not compulsory, to study also a third language. Spanish is the most popular choice, although the numbers are generally low.

\subsection{Need for SFL and everyone's right to study a SFL - the European context}

Another dilemma is related to the attitudes to SFL among adults and young people in Sweden (cf. section 2.2). We have seen that there is a lack of motivation for SFL studies, and there is a relatively low degree of understanding of the advantages of SFL knowledge. This is problematic in light of the European Union's language policy (European Commission, 1995). Since Sweden joined the EU in 1995, the ambition of the Swedish government has been to increase the number of students of an additional FL and to make the aims of the syllabus more attainable than before (Skolverket, 2000), but the situation does not seem to have changed, when it comes to numbers and attitudes (cf. Tholin, 2017). 
A look at other European countries via Eurostat Newsrelease (2017) confirms that English and French are the two main foreign languages in Europe during lower secondary education, English being most studied. French is studied by all pupils in Luxembourg and it is also the top foreign language studied in Ireland and Belgium. In addition, French is the second most popular foreign language and it is studied at lower secondary level in nine European Member States, with the highest shares of learners recorded in Cyprus, Romania, Portugal, Italy, and the Netherlands. German is the next most studied FL in eight Member States, with the highest shares being registered in Denmark, Poland, and Slovakia. Furthermore, it is studied by all school learners in Luxembourg. Spanish is most popular in Sweden and France.

Looking at the European figures, it is striking how they take official or unofficial second languages into account. In Finland, the official language Swedish, which is also the mother tongue of a linguistic minority, is an opitional SFL. In Iceland, Danish is studied for historical reasons. French has its role in Luxemburg and Belgium, where it is the mother tongue of several inhabitants. The fact that the Swedish society includes large groups of speakers of minority languages (e.g., Finnish, Arabic, Persian) is also sometimes brought up in the debate on SLFs, pointing out the importance of taking advantage of existing competencies by developing young speakers' proficiency levels and literacy in their mother tongues or heritage languages.

Studying one's mother tongue is possible within the Language choice and studies give grades and follow syllabuses. However, no credit implements are rendered. The implementation of mother tongue tuition is scarcely researched, and more studies would help understanding the construction Language choice as a whole. Alongside three non-compulsory modern languages, and mother tongue tuition, we here find three compulsory school subjects: Swedish, English, and Swedish as a second language, these rendering no second grade if studied within the Language choice, however. The conclusive picture is shattered.

\section{Conclusions and prospects}

As shown, a new curriculum was introduced in 1994, according to which all students had to choose a language, where almost always French, German or Spanish was - and is - one of the options. New curricula, keeping the model from 1994, were introduced in 2000 (Skolverket, 2000) and again in 2011 (Skolverket, 2011b). As demonstrated by Tholin (2017), a number of reforms, intended to enhance the study of SFLs, have hardly affected the situation.

The existing possibility to switch from Modern languages to additional studies in Swedish and/or English, is an option that many students choose, and therefore everyone does not learn a SFL in the Swedish compulsory school. Making SFL studies mandatory in Swedish lower secondary school is a pending issue. Recently (June 2018), the Swedish National agency for education made a recommendation to the government to abolish the Swedish/English option. ${ }^{15}$ The Swedish Language Teachers' Association, SPRI, have pronounced themselves positive to the recommendation. Because a number of pupils currently abandon Modern languages and switch over to additional studies in Swedish and/or English, this is a move that could make more students learn a SFL. Furthermore, preliminary results from a teacher survey in the ongoing TAL project on the Modern languages subject in Swedish lower secondary school, mentioned earlier, indicate that a 
considerable majority of SFL teachers in lower secondary school (68\%) currently seem to be in favour of changing the status of the subject from optional to obligatory (Erickson et al., 2018). There will be reason to return to this issue in due course, when more analyses of the data from the survey have been made.

As from the autumn semester 2018, a new time plan has been introduced in the Swedish compulsory school. This means that instead of leaving it to schools to decide how to distribute the stipulated number of teaching hours per subject across the nine years (320 for the Language choice/Modern languages), the instruction time is defined for three stages: school years 1-3, 4-6 and 7-9. For Modern languages, the starting time will be school year 6 at the latest, consequently not year 6 or 7, which has been the case since 1994. According to the binding time plan, the number of teaching hours for the SFL will be 48 during school years 4-6 (in the vast majority of cases, year 6) and 272 for years 7-9. This creates certain problems for a number of schools, especially on the countryside, where, traditionally, children change schools between school years 6 and 7. In those schools for younger children (up to year 6) where there are no teachers of Modern languages, the basic decision to make will then be who should travel: teachers to students or students to teachers, or if the children should perhaps change schools a year earlier than before, between years 5 and 6 .

Furthermore, grades for SFLs on a six-point scale are from now on to be awarded as from the autumn semester in school year six, instead of a year later, which has been the case so far. Consequently, teachers will have to award their students' first grades for French, German and Spanish based on c. 24 hours of instruction. This is obviously a challenge and an issue that can be discussed from several perspectives, ranging from validity and reliability to impact and ethics.

Finally, it should be mentioned that the rule saying that instruction in SFL has to start in school year 6 has made some schools decide to cut down from previously offering three modern languages to only two. This is not formally incorrect, since the Education Act stipulates a minimum of two, but reactions have been strong from different stakeholder groups, not least parents.

The aim of the current article has been to give an overview of some of the issues regarding Second foreign languages in Swedish lower secondary school and hence to contribute to a knowledge basis for further research on the topic. As has been shown, the situation for the Modern languages is complex at different levels: the individual level as well as the pedagogical and the structural. A number of parallels can be drawn with the situation in other countries, but there are also distinct differences. This article was written in the autumn of 2018, at the time of the Swedish general election. Whether the question of SFLs will be of interest to the new government remains to be seen. However, considering the fact that languages have a crucial role in increasing communication and understanding between individuals as well as between nations, it would seem a self-evident item on the political agenda. 


\section{Endnotes}

1 This study is part of the research project Learning, teaching and assessment of second foreign languages: an alignment study on oral language, funded by the Swedish Research Council (grant 2015-01088).

2 English instruction today starts in school year 3, at the latest.

3 See https://www.skolverket.se/skolutveckling/statistik/sok-statistik-om-forskolaskola-och-vuxenutbildning?sok=SokC\&omrade=Betyg \%20\%C3\% A5rskurs\%209\&lasar $=2016 / 17 \&$ run $=1$

4 The NAE also proposed to maintain the option to study one's mother tongue or heritage language, as well as sign language for hearing students.

${ }^{5}$ https:// www.skolverket.se/for-dig-som-ar.../studie--och-yrkesvagledare/stod/ sprakvalet-i-grundskolan

${ }^{6}$ www.tal.lu.se

${ }^{7}$ European survey over the current public opinions in the Member States.

8 Terminology from van den Akker, Kuiper and Hameyer (2003).

9 In the current system, a 6-point grading scale (A-F) is used, with F as a non-pass, E as a minimal Pass and $\mathrm{A}$ as the highest grade level. In the aggregation officially made, an $\mathrm{F}$ renders a zero, an E value 10, a C 15, and an A 20.

10 Not including two options taken by less than $1 \%$ of the cohort: other languages than French, German and Spanish within the Language choice, and students' choice of a third foreign language; for both these two, averages are higher than for all other subjects.

11 Tests for four levels of English are available, for Swedish steps 2, 4, 5 and 6 (roughly levels A2.1, B1.1, B1.2 and B2.1). Assessment materials for French, German and Spanish are offered for steps 2, 3 and 4 (approximately A2.1, A2,2 and B1.1). Both for English and Modern languages, subtests focusing on Receptive skills, Oral production and interaction, and Written production and interaction are produced. 12 https://nafs.gu.se/english/information

For further information about the Swedish national assessment system for foreign languages, see Erickson and Åberg-Bengtsson (2012).

13 https://www.gymnasieguiden.se/informeras/raekna-ut-ditt-meritvaerde

14 The relevant statistics can be searched for at https://www.skolverket.se/skolu tveckling/statistik/sok-statistik-om-forskola-skola-och-vuxenutbildning?sok= SokC\&verkform $=$ Grundskolan\&omrade=Betyg $\%$ 20\% C3\% A5rskurs \% 209\&lasar=2 017/18\&run=1

15 https://www.skolverket.se/om-oss/press/pressmeddelanden/pressmeddelanden/ 2018-06-18-forslag-for-att-fler-elever-ska-lasa-sprak

\section{References}

van den Akker, J., Kuiper, W., \& Hameyer, U. (Eds.). (2003). Curriculum perspectives: An introduction. Dordrecht: Kluwer Academic Publishers.

Andered, B. (2001). Europarådets Framework - en inspirationskälla för de svenska kursplanerna [The Common European Framework of Reference - a source of inspiration for Swedish syllabuses]. In P. Malmberg \& R. Ferm (Eds.), Språkboken - en antologi om språkundervisning och språkinlärning [The language book - an anthology on language teaching and language learning] (pp. 26-37). Stockholm: Skolverket/Liber Distribution. 
Arevik, N. (2012, March 28). Lärarutbildare ser stora brister [Teacher educators note severe weaknesses]. Lärarnas tidning. Retrieved from https://lararnastidning.se/ lararutbildare-ser-stora-brister/

Bardel, C., \& Novén, B. (2012, November 11). Engelska räcker inte i en globaliserad värld

[English is not enough in a globalized world]. Dagens Nyheter. Retrieved from https://www.dn.se/arkiv/kultur/engelska-racker-inte-i-en-globaliserad-varld/

Bertilsson, E., Börjesson, M., \& Broady, D. (2009). Könsmönster i rekryteringen till svenska lärarutbildningar 1977-2007 [Gender patterns in the recruitment for Swedish teacher education programs]. Rapporter frän forskningsgruppen för utbildnings- och kultursociologi. [Reports from the research group for educational and cultural sociology]. Uppsala: SEC, EDU, Uppsala universitet.

Bratt, I. (1977). Engelskundervisningens framväxt $i$ Sverige. Tiden före 1850 [The growth of English language education. The time before 1850]. ÅSU 139. Uppsala: Föreningen för svensk undervisningshistoria.

Bratt, I. (1984). Engelskundervisningens villkor i Sverige 1850-1905 [The conditions for English language education 1850-1905]. ÅSU 156. Uppsala: Föreningen för svensk undervisningshistoria.

Cabau-Lampa, B. (2007). Mother tongue plus two European languages in Sweden: unrealistic educational goal? Language Policy, 6(3-4), 333-358.

Cardelús, E. (2015). Motivationer, attityder och moderna språk: En studie om elevers motivationsprocesser och attityder vid studier och lärande av moderna språk [Motivations, Attitudes and Modern Languages. A study of students' motivational processes and attitudes while learning foreign languages]. Doctoral dissertation, Stockholm University, Sweden.

Carrai, D. (2014). Fremmedspråk på ungdomstrinnet. En analyse av motivasjon og andre faktorer involvert i elevenes fagvalg og tilfredshet med faget [Foreign languages in secondary school. An analysis of motivation and other factors involved in students' choice of and satisfaction with their subjects]. Doctoral dissertation, Institutt for lærerutdanning og skoleforskning, Oslo universitet, Norway.

Carroll, J. B. (1975). The teaching of French as a foreign language in eight countries. Stockholm: Almquist \& Wiksell; New York: John Wiley \& Sons.

Council of Europe. (2001). Common European Framework of Reference for Languages: Learning, teaching, assessment. Cambridge: Cambridge University Press.

Dörnyei, Z., \& Ushioda, E. (2009). Motivation, language identity and the L2 Self. Clevedon: Multilingual Matters.

Elfving, E. (2002). Språkdöden i den svenska skolan [The death of languages in Swedish schools]. LMS-Lingua, 5, 52-53.

Erickson, G. (2017). Holistic peer analyses of national tests in relation to the CEFR. Presentation at EALTA CEFR Special Interest Group Meeting, London. Retrieved from http://www.ealta.eu.org/resources.htm\#Events

Erickson, G., \& Pakula, H.-M. (2017). Den gemensamma europeiska referensramen för språk: Lärande, undervisning, bedömning - ett nordiskt perspektiv [The Common European Framework of Reference for Languages - a Nordic Perspective]. Acta Didactica Norge - nasjonalt tidsskrift for fagdidaktisk forsknings- og utviklingsarbeid, 11(3), 1-23. Retrieved from https://www.journals.uio.no/index.php/adno

Erickson, G., \& Åberg-Bengtsson, L. (2012). A collaborative approach to national test development. In D. Tsagari \& I. Csépes (Eds.), Collaboration in language testing and assessment (pp. 93-108). Frankfurt am Main: Peter Lang.

Erickson, G., Österberg, R., \& Bardel C. (2018). Lärares synpunkter på ämnet Moderna språk - en rapport från projektet TAL [Teachers' opinions on the subject Modern languages - a report from the TAL project]. Lingua, 2, 8-12.

European Commission. (1995). White paper on education and training: Teaching and learning - towards the learning society. COM (95), 590 final, 29 November 1995.

European Commission. (2012a). Eurobarometer 386. Europeans and their languages. Retrieved from http://ec.europa.eu/commfrontoffice/publicopinion/archives/ebs/ ebs_386_en.pdf 
European Commission. (2012b). First European Survey on Language Competences: Final Report. Retrieved from https://www.researchgate.net/publication/262877352_First_ European_Survey_on_Language_Competences_Final_Report

European Commission. (2017). Key data on teaching languages at school in Europe (2017 Edition). Eurodyce Report. Retrieved from https://eacea.ec.europa.eu/nationalpolicies/eurydice/content/key-data-teaching-languages-school-europe---2017-edition_en

European Council. (2002) Presidency Conclusions. Barcelona, 15 and 16 March 2002. Retrieved from http://ec.europa.eu/invest-in-research/pdf/download_en/barcelona_ european_council.pdf

Eurostat Newsrelease. (2017, February 23). Foreign Language Learning. 33/2017. Retrieved from http:/ / ec.europa.eu/eurostat/web/products-press-releases/-/3-23022017-AP

Fahlén, Å. (2018, January 23). Kommun avvecklar franskan i alla sina högstadieskolor [Municipality takes away French in all their secondary schools]. Dagens Nyheter. Retrieved from https://www.dn.se/arkiv/debatt/kommun-avvecklar-franskan-ialla-sina-hogstadieskolor/

Falk, Y., Lindqvist, C., \& Bardel, C. (2015). The role of L1 explicit metalinguistic knowledge in L3 oral production at the initial state. Bilingualism: Language and Cognition 18(2), 227-235.

Hammar, E. (1981). Franskundervisningen i Sverige fram till 1807. Undervisningssituationer och lärare [French language education in Sweden until 1807. Teaching and Teachers]. ÅSU 148. Uppsala: Föreningen för svensk undervisningshistoria.

Hemmingson, A. (2007). Hopp eller avhopp? [Hope or Defection?]. Stockholm: Stockholms Akademiska Forum.

Henriksson, S.-O. (1960). Tyskundervisningen i Sverige. Historisk studie med särskild hänsyn till metodiska synpunkter på undervisningen $i$ främmande språk [German language education in Sweden. Historical study focusing on methodological considerations regarding foreign language education]. Licentiate thesis, Kungl. Universitetet i Stockholm, Sweden.

Henry, A. (2009). Gender differences in compulsory school pupils' L2 self-concepts. A longitudinal study. System 37(2), 177-193.

Henry, A. (2012). L3 motivation. Doctoral dissertation, Göteborgs universitet, Sweden.

Henry, A., \& Apelgren, B.-M. (2008). Young learners and multilingualism. A study of learners' attitudes before and after the introduction of a second foreign language to the curriculum. System 36(4), 607-623.

Holmer, A.-C., Gerdin, S.-E., \& Söderberg, A. (2001). Moderna språk - obligatorium på grundskolan? [Modern languages - mandatory in lower secondary school?]. LMS Lingua, 2, 11-14.

Hyltenstam, K. (2004). Engelskan, skolans språkundervisning och svensk språkpolitik [English, language education in school, and Swedish language politics]. Svenska språknämnden (Ed.), Engelskan $i$ Sverige. Språkval $i$ utbildning, arbete och kulturliv [English in Sweden. Language choice in education, work and cultural life] (pp. 36110). Stockholm: Norstedts.

Lalander, C. (2014). Diagnostiskt läsförståelseprov i början av lärarutbildningen med inriktning mot språk [Diagnostic reading comprehension test in the beginning of language teacher education]. Studies in Language Education 11. Licentiate thesis, Stockholm University, Sweden.

Larsson, Å. (2013, November 13). Många åsikter om den nya lärarutbildningen [Many views on the new teacher education program]. Skolvärlden. Retrieved from http://skolvarlden.se/artiklar/manga-asikter-om-nya-lararutbildningen

Lärarnas Riksförbund. (2016). Språk - så mycket mer än engelska: en rapport om moderna språk [Languages - so much more than English: a report on modern languages]. Stockholm: Lärarnas Riksförbund.

Lewis, E. G., \& Massad, C. E. (1975). The teaching of English as a foreign language in ten countries. Stockholm: Almquist \& Wiksell; New York: John Wiley.

Marklund, S. (1985). Skolsverige 1950-1975. Del 4. Differentieringsfrågan [Sweden's school system, 1950-1975. Part 4. The differentiation issue]. Stockholm: Liber Utbildningsförlag. 
Riis, U., \& Francia, G. (2013). Lärare, elever och spanska som modernt språk: Styrkor och svagheter - möjligheter och hot [Teachers, students and Spanish as modern language: Strengths and weaknesses - opportunities and threats]. Uppsala University: Fortbildningsavdelningen för skolans internationalisering [Centre for Professional Development and Internationalisation in Schools].

Riksrevisionsverket. (2014). Statens dimensionering av lärarutbildningen - utbildas rätt antal lärare? [National sizing of teacher education - is the adequate number educated?] RIR 2014:18. Stockholm: Riksrevisionen. Retrieved from https://www.riksrevisionen.se/ rapporter/granskningsrapporter/2014/statens-dimensionering-av-lararutbildningen--utbildas-ratt-antal-larare.html

Skolinspektionen. (2010). Moderna språk [Modern languages]. Kvalitetsgranskning. Rapport 2010:6. Stockholm: Skolinspektionen.

Skolverket. (2000). Språk. Grundskola och gymnasieskola. Kursplaner, betygskriterier och kommentarer [Languages: Compulsory school and secondary school: Syllabuses, grading criteria, and comments]. Stockholm: Skolverket.

Skolverket. (2004). Engelska i åtta europeiska länder: En undersökning av ungdomars kunskaper och uppfattningar [English in eight European countries. A study of adolescent students' competences and perceptions]. Stockholm: Skolverket (author: Gudrun Erickson).

Skolverket. (2011a). Redovisning av regeringsuppdrag angående utveckling av språkvalen moderna språk och svenska/engelska [An account of a government commission regarding the language options Modern languages and Swedish/English]. Dnr. 01-2010:526. Stockholm: Skolverket.

Skolverket. (2011b). Läroplan för grundskolan, förskoleklassen och fritidshemmet 2011 [Compulsory school curriculum]. Stockholm: Skolverket.

Skolverket. (2012a). Internationella språkstudien 2011 [The international language study 2011]. Rapport 375. Stockholm: Skolverket.

Skolverket. (2012b). Bedömning av språklig kompetens - En studie av samstämmigheten mellan Internationella språkstudien 2011 och svenska styrdokument. Skolverkets aktuella analyser 2012 [Assessment of language competence - A study of the alignment between the international language study 2011 and Swedish curricula. Current analyses by the Swedish National Agency for Education 2012]. Stockholm: Skolverket.

Skolverket. (2013). Att tala eller inte tala spanska: En fördjupning av resultaten i spanska från Internationella språkstudien 2011 [To speak or not to speak Spanish: An in-depth study of the results of the European Language Study 2011]. Stockholm: Skolverket.

Skolöverstyrelsen. (1978). Förslag till förändring av grundskolans läroplan [Proposed changes in the curriculum for compulsory school]. Stockholm: Liber Utbildningsförlaget.

Skolöverstyrelsen. (1991). Undervisning i franska och tyska $i$ grundskolan: Redovisning av en enkätundersökning 1987/88 [The teaching of French and German in compulsory school: Report on a questionnaire survey 1987/88]. Skolöverstyrelsens rapportserie, R 91:12. Stockholm: Skolöverstyrelsen.

Söderberg, C. (2011). Språklärarens stora blå? En samling texter om gemensam europeisk referensram för språk [Language teachers' Big Blue? A collection of texts on the Common European Framework of Reference]. Uppsala: Fortbildningsavdelningen för skolans internationalisering.

Sörensen, C. (1999). Språkvalet $i$ grundskolan - en pilotundersökning [Language studies in compulsory school-A pilot study]. Stockholm: Skolverket.

Sylvén, L. K., \& Sundqvist, P. (2012). Gaming as extramural English L2 learning and L2 proficiency among young learners. ReCALL, 24(3), 302-321.

Takala, S. (2013). The CEFR in use - Some observations of three Nordic countries. The impact of the CEFR in Catalonia. Barcelona: Barcelona APAC Monographs, 9, 9-18.

Tholin, J. (2017). State control and governance of schooling and their effects on French, German, and Spanish learning in Swedish compulsory school, 1996-2011. Scandinavian Journal of Educational Research, 1-16. Advance access at https://doi.org/10.1080/00313831.2017.1375004 
Tholin, J., \& Lindqvist, A. K. (2009). Språkval svenska/engelska på grundskolan - en genomlysning [Compulsory school language choice: Swedish/English: An in-depth look]. Borås: Högskolan i Borås.

Thorson, S., Molander Beyer, M., \& Dentler, S. (2003). Språklig enfald eller mångfald...? En studie av gymnasieelevers och språklärares uppfattningar om elevers val av moderna språk [Linguistic simplicity or diversity...? A study of secondary school students' and language teachers' perceptions of students' choice of modern languages]. UFL-rapport 2003:06. Göteborg: Göteborgs universitet.

Utbildningsdepartementet. (1994). Svensk författningssamling [Swedish Code of Statutes]. Retrieved from http://www.riksdagen.se/sv/dokument-lagar/dokument/svenskforfattningssamling/grundskoleforordning-19941194_sfs-1994-1194

Utbildningsdepartementet. (2017) Tillträde för nybörjare - ett öppnare och enklare system för tillträde till högskoleutbildning [Admission of beginners - a more open and simple system for admission to higher education]. SOU (2017:20). Stockholm: Regeringskansliet. Retrieved from https://www.regeringen.se/rattsliga-dokument/ statens-offentliga-utredningar/2017/03/sou-201720/

Österberg, R. (2008). Motivación, aptitud y desarrollo estructural: Un estudio sobre a actuación lingüística en aprendientes suecos de español L2 [Motivation. Aptitude and structural development: A study of linguistic performance in Swedish learners of Spanish L2.] Doctoral dissertation, Stockholms universitet, Sweden.

Received February 28, 2018

Revision received October 31, 2018

Accepted January 23, 2019 